\title{
Spatially Differentiated, Temporally Variegated: The Study of Life Cycles for a Better Understanding of Suburbia in German City Regions
}

\author{
Markus Hesse $^{1}$ (D) $\cdot$ Jan Polívka ${ }^{2}$ Christa Reicher ${ }^{3}$
}

Received: 4 October 2016 / Accepted: 13 October 2017 / Published online: 24 October 2017

(c) Springer-Verlag GmbH Deutschland 2017

\begin{abstract}
This paper takes a spatially differentiated and temporally variegated perspective on suburban areas. It proposes a conceptual framework for studying the temporal variation and related trajectories of the subject matter, with suburban lifecycles being the key to our analysis. In empirical terms, the paper summarises the findings of research undertaken in 12 selected locales of four major metropolitan regions in Germany. Against the background of assessing the broader socioeconomic development of these regions, detailed local case studies have been conducted in order to reconstruct past and current development trajectories. Our analyses detected particular life cycles (and related segments) in the study areas, based on age and social composition, the physical conditions of the built environment and broader developments in the real-estate market. The different cycles include, in most cases, growth, maturity, transi-
\end{abstract}

Prof. Dr. Markus Hesse

markus.hesse@uni.lu

Dr. Jan Polívka

jan.polivka@ils-forschung.de

Prof. Dipl.-Ing. Christa Reicher

christa.reicher@tu-dortmund.de

1 Institute of Geography and Spatial Planning, Campus Belval/Maison des Sciences Humaines, University of Luxembourg, 11, porte des Sciences, 4366 Esch-sur-Alzette, Luxembourg

2 ILS - Research Institute for Regional and Urban Development, Built Environment Division, Karmeliterstraße 6, 52064 Aachen, Germany

3 Fakultät Raumplanung, Fachgebiet Städtebau, Stadtgestaltung und Bauleitplanung, Technische Universität Dortmund, August-Schmidt-Straße 10, 44221 Dortmund, Germany tion and resilience, and they are also discussed in terms of their relevance for strategies responding to recent changes.

Keywords Suburban life cycles · Development trajectories $\cdot$ Place-making $\cdot$ German city regions

\section{Räumlich differenziert, zeitlich verschiedenartig: Lebenszyklen als Zugang zu einem besseren Verständnis von Suburbia in deutschen Großstadtregionen}

Zusammenfassung Dieser Beitrag nimmt einen räumlich differenzierten und zeitlich verschiedenartig gerichteten Blick auf suburbane Räume vor. Es wird ein konzeptioneller Rahmen vorgeschlagen, um insbesondere der zeitlichen Variation im Entwicklungsverlauf von Suburbia auf den Grund zu gehen, wobei Lebenszyklen den Schlüssel zu einem neuen Verständnis dieser Raumkategorie bilden. In empirischer Hinsicht beruht der Beitrag auf den Ergebnissen von Fallstudien in 12 ausgewählten Standorten in vier Metropolräumen Deutschlands. Unsere Analysen konnten verschiedene Lebenszyklen dieser Standorte identifizieren, ausgehend von Alter und sozialer Mischung, den baulichen Konditionen sowie der Entwicklung der Immobilienmärkte. Die verschiedenen Zyklen beinhalten in aller Regel Phasen des Wachstums, der Reife, der Transition und der Resilienz, und verhalten sich je spezifisch auch mit Blick auf Strategien zum Umbau von Suburbia.

Schlüsselwörter Suburbane Lebenszyklen . Entwicklungslinien · Place-making · Stadtregionen in Deutschland 


\section{Introduction}

In contrast to earlier periods of suburbanisation, recent dynamics of urban and metropolitan development are characterised by changing social, economic and political framework conditions. At first glance, such trends seem to indicate a resurgence of cities and an associated decline of suburbs and peripheries (Dittrich-Wesbuer/Knapp/ Osterhage 2010). However, closer inspection reveals the simultaneous occurrence of growth, stagnation and demographic or economic decline, which seems to happen at various locales of the city region: in the centre, on the fringe, and in peripheral areas as well. Taking international developments into account, it seems obvious that ageing, stagnation and abandonment can be observed both in urban cores and in suburban areas, with the full range of cities' trajectories including both patterns of resurgence (Cheshire 2006) and divergence (Clarke/Martin/Tyler 2016). This also means that the relation between core and fringe is becoming more variegated, depending on the general framework conditions that provide economic and/or demographic growth or decline, and on the very capacity of these areas to adapt to such changes.

Urban discourses have only recently shown awareness of such trends, at least in the continental European context. ${ }^{1}$ Key issues that have been emphasised by new suburban studies include the disadvantageous locality of suburbs and their demographic and physical ageing, a change in the preferences of major groups that determine the demand for housing, and also changing patterns of governance in cities and suburbs. This recent suburban discourse is welcome as it adds to urban debates that have been unbalanced given their strong emphasis on inner cities and re-urbanisation. Nonetheless, the new suburban discourse appears selective as yet, as it mostly focuses on suburban housing and, quite substantially, on single-family homes (see e.g. WüstenrotStiftung 2012; Lauster 2016), the perspective of suburban industrial and commercial areas remains under-assessed.

The two systems that are professionally concerned with suburbia - scholarship and practice - are particularly challenged by these developments and discourses. From the research perspective, it is notable that the traditional understanding of suburban areas, which Harris (2010: $27 \mathrm{ff}$.) summarised as i) a localisation beyond the core city, ii) relatively low density and iii) relatively low age, is about to change in the course of increasing urbanisation. It is rather the case that urban growth has unfolded in the context of

\footnotetext{
1 As to German developments, see for example Prigge (1998), Kuhn (2002), Menzl (2007), Hesse (2012); for the international context, the overviews provided by Siedentop and Fina (2012), Keil (2013), Scott, Cartera, Reeda et al. (2013), Nijman (2015) or Salet and Savini (2015) can be considered useful here.
}

a space-time continuum, which is transforming space across politico-administrative borders; this has created a variegated built environment, consisting of more than just single-family homes. Accordingly, socioeconomic and planning structures are more diverse than is usually assumed. From the perspective of practice, the important question of strategic orientation (whither the suburbs?) has so far remained unanswered. On the one hand, it remains unclear what municipalities should expect from areas they consider to be suburban: further growth and development or a recentralising of development towards the urban core? There are almost no blueprints available that could guide urban planning in this respect, particularly as the issue of actors and institutions in suburbia has rarely been addressed (Polívka 2016). On the other hand, major challenges in defining and delineating suburban space have emerged recently (Forsyth 2012). Suburbs are not only becoming urbanised and have assumed properties that were formerly used to describe the 'city', but they have also become a major element of the polycentric city region. Clear distinctions between core and periphery are increasingly difficult to make, given that locality, age, social stratification and the built environment appear as heterogeneous and manifold as is the case in core urban areas. This has led authors also to understand the present phase of suburbanisation as post-suburban (see Phelps/Wood/Valler 2010; Mace 2013). These observations do not necessarily contradict the perception of re-centralisation as being indicative of contemporary urban development as a whole: cities and city life are simply more variegated than the assumption of general trends and problems - such as a renaissance of the core and a decline of the fringe would suggest. ${ }^{2}$

Our approach is guided by three perspectives that have not been part of the standard repertoire of empirical suburban studies to date. Firstly, we pursue an analysis which is not predetermined by normative, and thus primarily negative, claims about suburbia. Secondly, besides spatial differentiation, this study focuses also on investigating the temporal variation in the development trajectory of suburbia, thus taking up a claim made by McManus and Ethington (2007: 327) who emphasised that "every suburb, once planted, eventually evolves in a way that incorporates both continuity and change, in terms of the built and social fabric". Consequently, the authors proposed adding the following to future research agendas on suburbia: "the related inscrip-

\footnotetext{
2 A more differentiated, pluralistic approach to the study of suburbia has been pursued primarily at international levels (see e.g. Wunsch 1995; Harris/Larkham 1999; Clapson 2003; Phelps/Parsons/Ballas et al. 2006; McManus/Ethington 2007; Hanlon 2010; Phelps/Wood 2011 or Keil 2013), while the German-speaking realm followed only recently (Sieverts 1997; Schenk/Kühn/Leibenath et al. 2012); only the debate of the "Zwischenstadt" or 'in-between city' has found some recognition in the international community since then (Keil/Addie 2015).
} 
tion of time, or history, in suburban landscapes; successive forms of construction; and also related group succession in suburban areas" (McManus/Ethington 2007: 328). Looking at the different cycles of suburbanisation clearly reveals the multitude of areas, habits and practices that are characteristic of the current state of suburbia. Thirdly, as our research is based on a selection of empirical case studies conducted in German city regions, it aims to contribute to a genuinely Continental European view of suburbanisation and suburban areas, absent from meta-narratives and terms such as sprawl or leapfrogging, which have dominated Anglo-American debates for some time. Our aim is to discuss the historically specific trajectories of urban and suburban development that are shaping European city regions, and to detect means for intervention where deemed appropriate.

The remainder of this paper is organised as follows. After this introduction, we present the conceptual model of suburban lifecycles and provide some foundations for the related analysis. The subsequent section of the paper explains the methodology of our research. Section 4 summarises the findings of our empirical research at the regional (macro), local urban and neighbourhood levels (meso and micro) and synthesises our thoughts on the role of temporal variation as it discusses municipal strategies dealing with suburban change. The final Section 5 presents some concluding thoughts on our research and discusses possible ramifications for future research and practice.

\section{Life cycles in suburban areas}

In order to develop a systematic, conceptual framework for analysis, we follow the idea of regularities in the changes in certain descriptors such as population, occupation or the condition of the built environment. Our analysis of the temporal variation and path development of suburban areas remains descriptive - our method does not claim to provide a comprehensive set of explanations. The study concentrates on integrating the particular phases and cycles into a broader context of the suburban system and - as far as possible - aims to describe interdependencies of trigger factors as well as of the local and regional frameworks. This distinguishes the approach from a static spatial analysis. Such phases comprise, in most cases, growth, maturity, transition and resilience. The latter describes the capability of a system to counteract decline or even to achieve a development turn (Setterfield 1997). The phases develop into cycles when temporal periodic changes occur, following a certain logic determined by definable factors and strategies. Our aim is to decipher this logic, to reconstruct the current development trajectories of suburban districts, and to identify those factors that are responsible for triggering different phases or cycles of developments. We assume we are dealing with cycles rather than phases when temporal or periodic changes occur, following a certain logic which is determined by events or factors located both inside and outside the area.

The idea of life cycles was initially applied in economic contexts, while in urban and spatial development it was practised by the school of social ecology in urban sociology (Chicago School), particularly by Park (1952). Hoover and Vernon (1959) developed these thoughts further in their study of life-cyclic changes in urban neighbourhoods in New York City. Their application of urban lifecycles became most popular in related works. Based on the empirical investigation of a huge number of urban areas, they distinguished several phases or stages: development, transition, decline, thinning and recovery. Change between different phases was based not only on the analysis of classical indicators such as population or occupation, but also took into account density, social status or segregation: that is the unequal distribution of certain properties among different groups across space. Selective inward and outward migration of certain populations was considered to be the central factor determining life-cyclic changes. The phase of recovery also includes elements of neighbourhood change associated with the process of gentrification.

Life cycle approaches belong to a certain standard repertoire in evolutionary economic geography (Martin 2012), but already enjoyed a prominent place in urban studies during the 1970s and 1980s. Concerning the overall development of population and occupation in urban regions (core and periphery), the model of phases of urban development developed by van den Berg, Drewett and Klaassen (1982) became best known. However, the mainstream of related analyses emphasised the intra-urban level (Roberts 1991; Temkin/Rohe 1996). Particularly in North America, the decline of inner-city neighbourhoods and those neighbourhoods that were close to the inner city received significant attention. The seemingly sequential development of disinvestment, segregation and selective migration was interpreted against the background of the idea of a lifecycle. More advanced investigations studied the development of real-estate markets (Gotham 2006), consumer preferences (Clark/Lloyd/Wong et al. 2002) or economic restructuring.

Temporal patterns of development were not only studied in inner-city districts but also in suburban areas. Choldin, Hanson and Bohrer (1980) investigated the change in status of selected suburban areas according to a transformation of life-cyclic dynamics, assuming that suburban areas can undergo decline subsequent to phases of steady growth in a similar way to that of core urban areas. More recent empirical illustration of the degree of such changes can be found in Hanlon (2010). In the European context, related approaches have been used for empirical research, for instance by Bizer, Dappen, Deffner et al. (2008) who studied 
the built fabric of urban neighbourhoods, or by Friedrich (2003) who studied the transformation of housing at the urban fringe in Zurich, Switzerland.

Following the ideas of Choldin, Hanson and Bohrer (1980), we share the view that suburban areas do change their development trajectory over time, depending on the respective framework conditions and their capability to respond to these changes - as indeed has been common in other urban areas. We also assume that the associated restructuring of these areas is highly differentiated, depending on each area's positioning in the lifecycle and given the various subjects of analysis (people, community, buildings for housing, commercial uses, infrastructure). In this context, our study uses the lifecycle model as a conceptual directory for analysis of the ongoing transformation of suburban space (Polívka 2016). It is not used as a formally rigid explanatory model, which would underline a causally determined hypothesis regarding the development trajectory of suburban space. It is more an analytic concept which allows us to focus on the central characteristics of the research object and its transformational behaviour. The elements of this concept include the units of spatial analysis (residential area, service or production-related quarter), the four phases of the lifecycle (growth, maturity, transition and resilience), and the layers of life-cyclic change (inhabitants, infrastructure, buildings, image etc.).

\section{Methodology and research methods}

This paper is based on findings generated by a research project that was carried out on behalf of the German federal government (BMVBS 2013b). The research was conducted between 2010 and 2012/2013 and included both empirical and conceptual techniques and data sets. The analysis of secondary data was combined with primary research, particularly comprising the use of mapping techniques and a series of 22 expert interviews. As a conceptual background, we developed a model of life cycles that explains the development trajectories of suburban areas. It was used as a heuristic frame that guides our empirical research, following the assumption that suburban areas are rather differentiated, not only in spatial but also in temporal terms.

A macro-level data set for the years 1997 to 2009 was used for the basic analysis of our research; this originates from the national Continuous Spatial Screening ("Laufende Raumbeobachtung" (LR)), which - among other things defines urbanised regions. The data contain a broad variety of statistical indicators for German cities and are sorted into the categories of Core Cities and three further categories of Regional Urbanised Zones: Core Cities Supplementary Area, Closer Commuting Area and More Distant Commuting Area within the core city regions marking the suburban areas, as well as other categories defining areas outside the metropolitan context. This spatial typology and related data were used to identify different types of suburban spaces based on their development according to various demographic and economic aspects. Supported by a comprehensive set of data obtained from "Laufende Raumbeobachtung" and based on the factors of population distribution and commuting behaviour, such an approach avoided the usual bias caused by treating municipal borders as a line designating urban and suburban (BMVBS 2012: $52 \mathrm{f}$.) $)^{3}$, and allowed a better view of the functional context of the urban-suburban interrelations.

Following the definition of the Federal Institute for Research on Building, Urban Affairs and Spatial Development (BBSR), large agglomerations of at least 100,000 inhabitants served as the initial basis for the analysis. In a scattergram analysis (Figure 1) of the data we linked indicators with filters that cross-referenced cities and divided them into eight categories/types. To crossover the demographic and/or economic development data, the respective indicators were adjusted in an equilibrium. The characteristic values of the indicators were divided into septiles creating groups of the same size according to their ranking, without taking into account the size of the characteristic differences. The purpose of the classification is to represent a hierarchy of suburban spaces. As a division of the 50 major urban regions into septiles leaves one region (seven regions per septile), one region is also assigned to the middle septile. The compositional structural dimension is determined by the formation of a median dividing the two features 'aboveaverage' and 'below-average' increase in the area of settlement and infrastructure. A division is shown on the diagram based on the size of the settlement and infrastructural area growth (by size of the spheres representing the cities in the diagram) and on the above-average or below-average increase of the settlement and infrastructural area (orange for above-average, blue for below-average development). This division corresponds with the types shown in Figure 2. ${ }^{4}$

The indicators included:

- Demographic development 1997-2009 (LR-data on population, percentage of elderly ( 65 and older), balance of migration, balance of natural migration);

- Economic development 1997-2009 (LR-data on percentage of people entitled to social insurance contributions, percentage of employees in the tertiary sector, unemployment rate);

\footnotetext{
3 The "Laufende Raumbeobachtung" raw data for the years quoted is available from the Federal Institute for Research on Building, Urban Affairs and Spatial Development (BBSR).

${ }^{4}$ For further details see BMVBS (2013b: $74 \mathrm{ff}$.).
} 


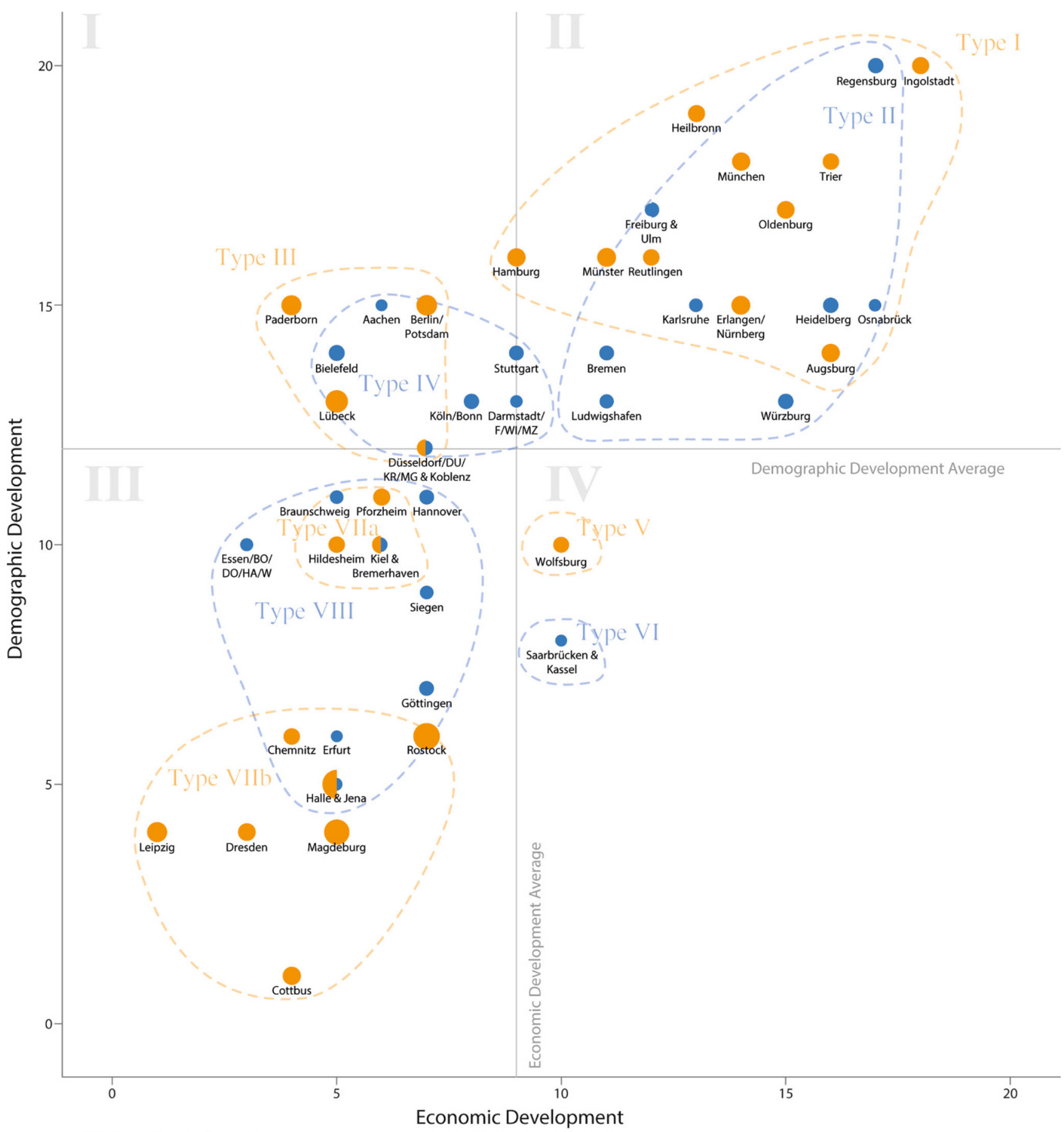

\section{Suburban Areas}

- Above-average development of settlement and infrastructural area

- Under-average development of settlement and infrastructural area

- Divergent development tendency within two equally rated regions Typology of suburban areas' development

\section{- County size per cent according to the development of settlement and infrastructural area $\begin{array}{llll}5 \% & 15 \% & 25 \% & 35 \% \\ & \text { between } 1996 \text { and } 2008\end{array}$}

Figure 1 Scatter-gram of cross-referenced demographic and economic development of urban regions, based on secondary data analyses Source: Laufende Raumbeobachtung BBSR (see BMVBS 2013b: 37) 
Figure 2 Typology of suburban areas' development based on secondary data analyses Source: Laufende Raumbeobachtung BBSR 2009-2011. Figure by BMVBS (2013b: 56) as modified by Polívka (2016: 108). For types of particular mesoor micro-areas, see BMVBS (2013b)

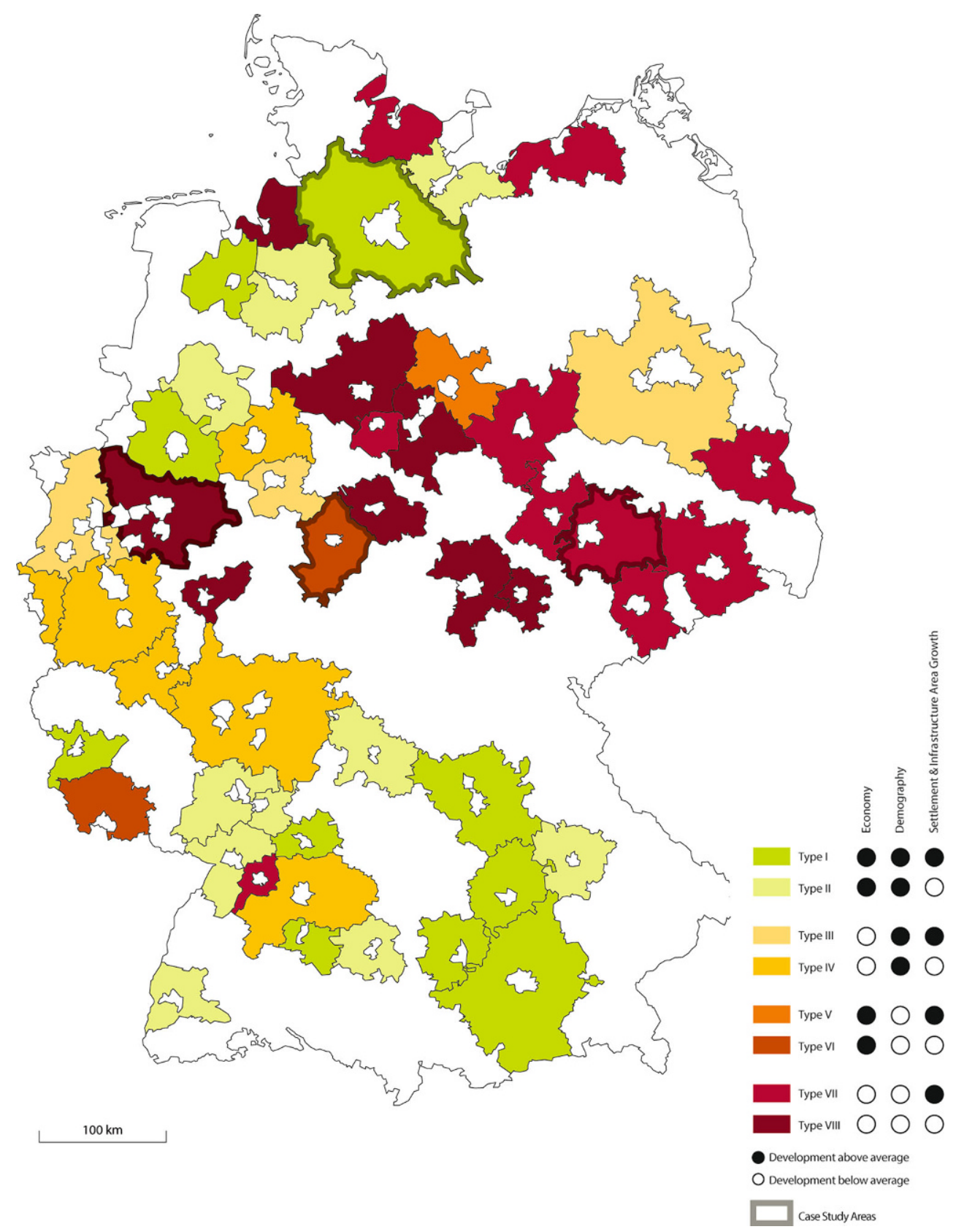

- Structural development 1996-2008 (LR-data on percentage of settlement and infrastructural areas).

Both core cities and suburban areas of the metropolitan regions were assigned to one of eight different categories in terms of their development tendencies in relation to the national averages (growth, stagnation, decline), distinguished by the combinations of the three indicators mentioned above. It was thus possible to compare the cores and the suburban areas for each region. This secondary analysis led to the identification of 12 case study areas, whereby three micro-scale suburban neighbourhoods were selected in each of a total of four differently typified macro-regions. These were investigated in order to reveal the variety of socioeconomic and demographic dynamics in suburbs.

The selection process for the case study areas included different spatial scales, i.e. the levels of city regions, municipalities and local districts and neighbourhoods. This procedure was layered, starting with a sorting at the level of city regions, then becoming more refined - depending on the assumed status of certain areas in the cycle, the concrete land use and social structure, and the related problems of suburban areas that were to be studied. This multi-dimensional approach and its breakdown to the micro study area 
was first tested in a pilot study. The complex breakdown of the Continuous Spatial Screening data and the multi-level approach identifying the macro, meso and finally also the micro levels was accompanied by two workshops in 2011 and 2012 attended by experts from research and practitioners from the pre-selected regions. This setting allowed the fine tuning of the methodological typification of the regions as well as a deepening of knowledge especially on the level of the meso and micro areas, thanks to the introduction of additional statistical data from the municipal governments and qualitative insights into local development processes.

Besides mapping the individual situational characteristics and state of each study area, in each of the cases we looked at the development patterns that had shaped them on three levels. First, on the regional (macro) level, we traced the conditions of the metropolitan area, which may be influential for the lower levels. This included the three framework conditions of demography, economy and settlement area development. Second, dynamics within the cities or neighbourhoods (meso level) that accommodate the particular case study areas were examined, both in terms of the indicators mentioned above and, additionally, regarding settlement development history and policies to which such areas are exposed. This approach was intensified by taking a closer look at the stakeholder structure on the meso level, and particular case study areas were analysed as to all aspects mentioned. Additionally, examination of the local stakeholder networks involved the physical analysis of concrete spatial aspects and the life cycles of buildings at the micro level, shedding light on the interaction between stakeholders and physical space, and thus including development paths in our model.

At the scale of the city region we therefore started with a comparative analysis of selected spatial, social and economic data from the "Laufende Raumbeobachtung"; the characteristics of the built environment were not taken into account at this stage. Only at the micro level did we target specific neighbourhoods and assess them using the maximum available number of statistical indicators on physical buildings for every particular neighbourhood. The decision to select the micro-locales was guided by local advice, generated from close communication with city officials and representatives from civil society. It included the following indicators: location in the urban area; building typologies and use; age of buildings; boundaries of the spatial and administrative units; and the availability of secondary data ${ }^{5}$ (in relation to demographics, economy, settlement structure, building trajectory at the level of the district).

\footnotetext{
5 The data on the district level regarding demographics, economy, settlement structure, and building trajectory were drawn from official planning documents of the municipalities such as settlement area analyses and development concepts (such cases are provided with citations).
}

Thus, identification of the case studies involved the assessment of different types of data. Firstly, a statistical overview was based on fine-grained analyses of secondary data that are available at local levels only. Secondly, a spatial analysis (land use, infrastructure, accessibility) and also situational mapping were carried out, overlaying the demographic and socioeconomic development trends of the case-study area and emphasising specific spatial dynamics. Thirdly, an overview of temporal dynamics and development patterns provides a lifecycle definition and defines stabilising strategies and the stakeholders. Our analytical findings and the related interpretation of 'problems' were validated through 22 expert interviews (four in each city region) with city officials and civil society/neighbourhood representatives, and also by consulting about 40 academics and planning practitioners through the organisation of two project-related workshops in 2011 (on methods) and 2012 (on interpretation).

\section{Empirical findings: the shifting phases and cycles in the life of suburbia}

\subsection{Phases in the life cycles of suburban areas}

In the following, the life cycle phases that were established are explained and the 12 case studies are categorised according to these phases. From the analysis and comparison of the case study areas, three basic life cycle phases can be distinguished. In the classic scenario, based on Hoover and Vernon (1959), Holling (1986), and Short, Hanlon and Vicino (2007), amongst others, these phases can be defined in order as growth, maturity and transition. Settlement areas in the growth phase are characterised in particular by activity in new building and an associated increase in population. In a multi-level comparison, a below-average age of the inhabitants is apparent, compared with the average age of inhabitants in the meso-area. The maturity phase is essentially characterised by the fact that the features of the growth phase are concluded. There is hardly any new building activity taking place, and the inhabitant structure has consolidated. The transition phase covers those quarters in which the stable features of the maturity phase are no longer discernible. On account of different influences and conditions, the phases within an area under consideration rarely proceed in the classic manner. Deviations arise as a consequence of the effect of local conditions and their dynamics, and interactions on all three spatial levels (macro, meso, micro). At the same time, individual deviations trigger control strategies and measures, which can be seen as a compensatory response with the aim of approximating the ideal state of a stable maturity phase. The variety of these 
Table 1 Study areas

\begin{tabular}{|c|c|c|c|c|}
\hline Macro area & $\begin{array}{l}\text { Meso area } \\
\text { Micro area }\end{array}$ & Zone of city region & $\begin{array}{l}\text { Micro } \\
\text { area type }\end{array}$ & Main focus of the area \\
\hline \multirow[t]{3}{*}{ Kassel } & $\begin{array}{l}\text { Vellmar } \\
\text { Musikviertel }\end{array}$ & Supplementary area & VI & Residential \\
\hline & $\begin{array}{l}\text { Ahnatal } \\
\text { Kammerberg }\end{array}$ & Closer commuting area & II & Residential \\
\hline & $\begin{array}{l}\text { Fritzlar } \\
\text { Roter Rain I-III }\end{array}$ & More distant commuting area & I & Residential \\
\hline \multirow[t]{3}{*}{ Leipzig } & $\begin{array}{l}\text { Leipzig-Altwest } \\
\text { Rückmarsdorf }\end{array}$ & Core city & III & Commercial, Housing \\
\hline & $\begin{array}{l}\text { Borsdorf } \\
\text { An der Parthenaue }\end{array}$ & Closer commuting area & III & Residential \\
\hline & $\begin{array}{l}\text { Grimma } \\
\text { Grimma West }\end{array}$ & More distant commuting area & VII & Residential \\
\hline \multirow[t]{3}{*}{ Ruhr area } & $\begin{array}{l}\text { Gelsenkirchen } \\
\text { Resser Mark }\end{array}$ & Supplementary area & VIII & Residential \\
\hline & $\begin{array}{l}\text { Herten } \\
\text { Bertlich }\end{array}$ & Supplementary area & VI & Residential \\
\hline & $\begin{array}{l}\text { Hamm } \\
\text { Römerstraße }\end{array}$ & Closer commuting area & II & Industry (trade) \\
\hline \multirow[t]{3}{*}{ Hamburg } & $\begin{array}{l}\text { Hamburg-Eimsbüttel } \\
\text { Burgwedel }\end{array}$ & Core city & IV & Supply centre/residential \\
\hline & $\begin{array}{l}\text { Quickborn } \\
\text { Quickborn West }\end{array}$ & Closer commuting area & VI & Residential \\
\hline & $\begin{array}{l}\text { Tornesch } \\
\text { Tornesch-Borstelweg }\end{array}$ & Closer commuting area & VI & Industry \\
\hline
\end{tabular}

strategies is described for particular case studies below and then summarised in the next section.

The micro area types are determined by the method which is described in Figures 1 und 2, broken down to and using data on the level of micro areas.

Among the German metropolitan areas, four study areas were chosen for further qualitative analysis. Three of them represent the types VI, VII and VIII (see Table 1). These show a below-average dynamic within the suburban metropolitan areas in two out of the three parameters of economy, demography and settlement area development (see Figure 2). These area types were presumed to probably be experiencing stagnation in the suburban housing market. To capture different regional contexts, two midsized, monocentric city regions -Kassel and Leipzig - and the polycentric Ruhr area were chosen. The macro area of Hamburg was selected as a comparative case demonstrating a contrary trend. The general aim was to grasp the logic of development at different stages of the settlement development cycle in order to understand development paths under specific circumstances.

In the case of Kassel, we mapped a slow but sustained suburbanisation process. Typical for many West German metropolitan areas, it includes both city fringes and adjacent villages and towns. The fastest development dynamics were experienced from the end of the 1950s until the 1970 s under conditions of demographic and economic growth (Interview 8 2012). Despite continued positive economic development, demographic as well as settlement trends then became negative. ${ }^{6}$ The socioeconomic dynamics of the region are below average, and its growth in terms of area is rather minimal (see Figures 1 und 2). At the same time, investment activity is increasingly being directed to the core city as a residential location.

Leipzig, on the contrary, was affected by an explosive suburbanisation process starting in the early 1990s. As a consequence of the reunification of Germany's East and West, uncoordinated development led to massive suburbanisation producing exurban peripheral exclaves. As the construction boom came to a halt in the late 1990s, it left behind a suburban landscape which blurred any borders between compact cities and villages. In the case of Leipzig, negative demographic development created the opportunity for the core city to fight back with radical strategies of urban containment. This pattern has simultaneously encouraged regional as well as intra-urban conflicts between the dominating city and its outskirts. The still growing or already maturing suburban areas struggled with infrastructural gaps and uncertain development strategies (Interview 12 2012; Interview 15 2012).

\footnotetext{
6 Data from Laufende Raumbeobachtung BBSR (1997/2009).
} 
The Ruhr area with its industrial, carpet-like settlement development shows a polycentric regional space. The conurbation is structurally characterised as suburban with cities closely adjoining one another (Reicher/ Kunzmann/Polívka et al. 2011). To some extent, they depict forms such as are also to be found in the regions of Rhine-Main and Rhine-Neckar or in the Stuttgart area (Sieverts 1997). At the same time, it shows a high degree of diversity in types of buildings and districts, as well as in social and demographic features (Polívka/Roost 2011). The Ruhr area's underlying demographic and economic development dynamics are rather distinct on both macro and meso levels, mirroring increasing nationwide diversification (see aggregated position of 'Essen/BO/DO/HA/W' in Figure 1; with $\mathrm{BO} / \mathrm{DO} / \mathrm{HA} / \mathrm{W}$ indicating the cities of Bochum, Dortmund, Hagen and Wuppertal).

In order to maintain a high degree of variety among the cases selected, Hamburg stands for metropolitan areas that are witnessing sustained growth levels and are facing stable and strong demand for both urban and suburban development (see Figure 1). The study focuses specifically on the existing, mature suburban settlements in transition.

\subsection{Findings of the case studies}

\subsubsection{Case study region: Kassel}

The macro case-study region of Kassel comprises the core city of Kassel and 55 additional associations of local authorities. The Kassel city region represents smaller to mediumsized city regions with a more rural surrounding area, qualified Type VI (see Figure 1). ${ }^{7}$ The city region had a total population of just below 320,000 in $2009^{8}$, and in recent decades it has been characterised by typical patterns of residential and commercial suburbanisation (Interview 8 2012; Interview 10 2012). The dynamism of this process has clearly weakened, even if there continues to be - albeit to a lesser extent - migration from the core city to the surrounding area or directly to the suburbs from beyond the city region. Ageing processes in the population and also among the buildings of the residential suburbs (mostly consisting of single-family homes) are already apparent in the 1997 and 2009 data $^{9}$ and additional statistic data from the local authority. On this basis, the meso level municipalities of Vellmar (supplementary area), Ahnatal (closer commuting area) and Fritzlar (more distant commuting area) were selected for closer investigation.

The Vellmar micro case-study area is situated in the northern vicinity of Kassel next to its administrative bor-

\footnotetext{
7 Data from Laufende Raumbeobachtung BBSR (1997/2009).

8 Data from Laufende Raumbeobachtung BBSR (2009).

9 Data from Laufende Raumbeobachtung BBSR (1997/2009).
}

ders, and creates a typical urban fringe. Detached family housing dominates three phased development sections erected between the late 1960s and the 1990s. The direct connection to Kassel's city centre via a tram line that has crossed the area since around 2000 makes it an attractive place to live. The high demand for housing in the wellconnected and equipped suburban area has led to a continuous maturation process based on generational turnover (Interview 8 2012; Interview 9 2012).

A similar situation in terms of interdependence between location and connectivity on the one hand and deviation from an 'ideal' life cycle on the other hand is found in the exurban detached family housing area of Kammerberg in Ahnatal (Interview 7 2012). This mono-structured suburban housing area is situated some $8 \mathrm{~km}$ beyond the Kassel city limits and was developed in several phases from 1962 onwards, with no connection to existing settlements. As a privately driven speculative product of the suburbanisation boom of the 1960s and 1970s, it experienced rapid growth during the first two decades. This came to an end in the 1980s and the last development areas established in the foremost area remain partly undeveloped. While the oldest areas are located close to a tram station and shopping area, later annexes are situated on the periphery, where the low demand has led to a prolonged growth phase and lower land prices, and thus lower densities. While the average age of the inhabitants is the lowest here, it is rising faster than in the older section. The 'situative mapping' (BMVBS 2013b: $68 \mathrm{f}$.) revealed that the older areas provide socially stable neighbourhoods and relatively good accessibility of services and public transport. It can be seen that transition in Kassel occurs continuously with the generational shift.

Fritzlar is a remote municipality of about 14,500 inhabitants located about $30 \mathrm{~km}$ south of Kassel. Its post-war suburbanisation was initially driven by the military base situated in the town. When the base was closed, housing demand dropped, underpinned by the static demographic situation of the region. In order to both retain and attract young families, the municipality offered a third settlement enlargement zone for semi-detached and detached housing in the Roter Rain neighbourhood, together with a new kindergarten. Local statistical data from the residents' register show the first section of the study area (Roter Rain I) from the $1970 \mathrm{~s}$ as one with a stable late maturity and a distinctly elderly population. However, the large plots are making the neighbourhood attractive for generational turnaround. The second section of the study area (Roter Rain II), developed since the 1980s, is more compact due to the relatively higher land and development costs of the time; it has since entered an early maturity phase guided by household consolidations and initial physical adjustments. The third new section designated after 2000 finds itself in a growth phase prolonged by low demand. This has led to 
zoning adjustments towards lower densities and larger plots. By creating a supply similar to the Roter Rain I section, but dissimilar to that of the Roter Rain II section, a competitive situation with section I evolved. In section II, sales with consequent purchases in section III have been documented, helping the growth phase to be accomplished despite the generally low investment demand within dispersed housing areas. This documents the interconnection of the development paths of life cycle phases with demography and the market situation (Interview 11 2012).

\subsubsection{Case study region: Leipzig}

The Leipzig region (macro area) and city (meso area) development strategy targets growth and concentration of both residential and service functions at the core and follows a conservation strategy in competing locations at the periphery of the city and beyond. Thus, both public and private investments are regulated and guided to the benefit of the core and existing developments. The deployment of the respective strategy depends heavily on the level of action and is affected by the (overall negative) socio-demographic conditions (Interview 12 2012). The case studies document how framework conditions and coordinated planning measures on macro and meso levels are used to influence development of particular micro areas, thus co-shaping their individual life cycles. Many of the suburban areas evolved after 1990 and, after more than 25 years of existence, entered into the stage of early maturity. Both population losses and population increases have occurred at the micro level in suburban residential quarters, a matter of the re-distribution of population and functions. With regard to growth, positive dynamics could only be assumed in Leipzig city (Interview 15 2012). For the macro case study region of Leipzig, the meso-areas chosen for investigation were Leipzig-Altwest (core city area), Borsdorf (closer commuting area) and Grimma (more distant commuting area), all of them having shrunk during the last decade.

The commercial area of Rückmarsdorf (Leipzig-Altwest) is a typical close-to-core suburban setting situated on the trunk road from Leipzig's city centre to the main motorways in the western part of the city. Attached to an existing village, Rückmarsdorf developed as a 36 ha large roadside commercial strip during the 1990s. In addition to a shopping mall, a hotel, service stations and car dealers, it also accommodates apartment and detached housing. The construction boom of the time led to a short-lived growth phase, which started in 1992 and ended before 1997. In the following twenty years, there was almost no new development despite the many remaining vacant lots. Even though some development in detached housing began after 2005, the lack of stock consolidation such as refurbishments, adjustments or upgrades, which typically occur in maturing settlements, remains a pressing issue. The commercial strip in particular has difficulties in this environment as it is not able to adjust to the continuously changing retail and service trends, thus losing competitive advantages to other areas. The delay in adjustments has led to physical, functional and in the case of housing - also demographic "over-ripening" (BMVBS 2013a: 102; BMVBS 2013b: 242) ${ }^{10}$ of the area, and in the end results in physical and functional deterioration. Here, the halt in development is a planned one. Since the amalgamation of Rückmarsdorf with Leipzig, the city has denied all applications from owners for building permission, virtually putting a stop to any future maturationrelated adjustments or transition strategies that would create a demand-adjusted area typical for settlements in late maturity. The city also shelved plans for an arterial road upgrade as well as other measures aimed at improving connectivity. This hinders further investment in the remaining empty lots. This strategy is in line with the city's emphasis on inner-city services and retail areas at the cost of the periphery.

The second case study in the Leipzig area shows a contrasting situation. The independent municipality of Borsdorf, located at the border of the city of Leipzig with about 8,000 inhabitants, is characterised by typical examples of zoning adjustments towards lower density, pursued during the growth phase in order to cope with the lack of demand at the time. In 1992, the municipality designated the An der Parthenaue development area of around 16 ha, leading to the construction of up to four-storey buildings with nearly 700 apartments in a rural setting, with 500 more intended to follow. As demand fell suddenly in 1996, the Borsdorf municipality (similarly to Fritzlar Roter Rain III in the Kassel region) did not adhere to its original growth plan for the area, but adjusted it three times until the year 2000, with the approval of the regional planning office, changing the zoning code to allow ever lower densities. The aim was to enable completion of the settlement as soon as possible and to create a typological mix of different population groups (Interview 12 2012). ${ }^{11}$

Grimma, a municipality with more than 30,000 inhabitants in 2014 (CIMA/Stadt Grimma 2015) and a central area of about 14,000 residents, is located some $25 \mathrm{~km}$ away from Leipzig and demonstrates a unique process of consolidation and transition, adjusting to changing conditions during different life cycle phases. The suburbanisation boom after 1990 was driven by a lack of good housing and a suburbanisation backlog. As the collapse of local state-owned

\footnotetext{
10 The source BMVBS (2013a) is classified information. However, the report can be obtained from the authors upon request. [please check if this is possible or explain how others can assess the raw data].

11 Statistical data from the Registry Office at Borsdorf City Hall, years 2002-2011, partly amended 2014.
} 
industries pushed the workforce to leave Grimma from mid1990s on, vacancies emerged in existing housing areas. The micro-study area of Grimma West consisted of a municipally owned industrial apartment housing complex that was built in three phases between the late 1970s and the 1990s with a total of 1,200 apartments. Here, the three sections of Grimma West share the same location and a similar physical setting, but their different ages allow a deeper insight into the life-cycle phases and their divergent development paths. By the end of the 1990s, the oldest section already accommodated many elderly households in a consolidation phase with little dedication (or potential) to follow the displacement of jobs (CIMA/Stadt Grimma 2002; Interview 13 2012; Interview 14a 2014). This section thus remained inhabited, though demographically over-matured. A slow but continuous growth in the number of vacancies has been compensated by an influx of seniors from surrounding peripheral villages who were forced to give up their rural life due to high age and a lack of infrastructure. With some barrier-free adaptations and senior apartment concepts, this area resembles an elderly oriented retreat. The second section, erected in the 1980s, suffered more strongly from the demographic outflux caused by the push factor of job losses among younger workers and the pull of good career opportunities offered in economically more successful regions. Here, the downsizing and scrapping of empty apartments provides evidence of the consolidation of the area. The last settlement section erected around and after 1990 was hit strongly by the end of the high demand during its growth phase. Since then it has struggled with vacancy rates of up to $20 \%$ of the total stock. As a consequence, this section suffers from market speculations, low rents, vacancies and social issues, accompanied by a negative image. As the section is relatively new, mortgages have not yet been paid off making scrapping and re-investment significantly more difficult (Interview 13 2012; Interview 14 2012; Interview 14a 2014).

\subsubsection{Case study region: Ruhr area}

The case study region of the polycentric Ruhr metropolitan region comprises the core cities of Bochum, Dortmund, Essen, Hagen and Wuppertal among its 53 municipalities. The residential structural growth of the Ruhr area is heading northwards in particular. The municipalities of Gelsenkirchen and Herten are situated on the central northern supplementary perimeter of the Ruhr. Gelsenkirchen falls under type VIII, Herten type VI. Through the pilot study and quantitative assessments, the case study municipalities of Gelsenkirchen, Resser Mark (supplementary area), Herten (supplementary area) and a commercial location in Hamm (closer commuting area) were selected as case studies (Interview 22 2014).
With its nearly 5,500 inhabitants, Resser Mark exhibits an ideal maturation process marked by a transition from a suburban housing area to an integrated diversified part of the city (Interview 20 2011). It had been initially developed between the existing settlement of Resse and the Ewald Coal Mine during the 1930s and experienced an intensive growth phase which lasted until the 1970s. By that time, the initial housing area had already experienced its maturity phase with inhabitant turnover as well as significant physical refurbishments, especially densification through extension of the originally modest houses into their generous gardens. The long growth phase firstly gave the opportunity for different types of housing including row and single-family houses as well as apartment buildings. Secondly, like Grimma, the long growth phase caused a timeshifted maturation process, which segmented the micro area into sections with different development paths according to housing type and age. Unlike Grimma, the intrinsic power to steer the transition came from local citizen initiatives and organisations. The functionally mixed area attracts young families, while the elder generation has the chance to move into a senior residence without leaving the area. The local church offers 32 row house rental units to growing families on the site of an abandoned church, thus increasing the generational turnover and securing the existence of schools and kindergartens, assets which make the area attractive for families (Interview 16 2012; Interview 16a 2014; Interview 21 2014).

Herten-Bertlich is an example of a socially integrated, over-matured but stable ex-urban residential quarter on the city's most distant outskirts. The area was developed in the 1930s for mining workers, although it grew most significantly throughout the 1950s and 1960s. The last large development from the 1980s provided some apartments for elderly mining workers. The mining tradition leaves the area as a closed enclave (BMVBS 2013a: 109; see also BMVBS 2013b: $229 \mathrm{f}$.). The high degree of internal satisfaction and local services, including community healthcare and a shopping centre in the vicinity, are incentives for the elderly to remain in the community. Vacant houses are quickly sold, mostly to family members or their direct contacts (Interview 17 2012; Interview 21 2014).

The Römerstraße area in Hamm represents the rare case of a maturing suburban commercial area. As mentioned for the case study of Rückmarsdorf, due to fast development in retail, office and production, life cycles in commercial areas are assumed to be faster than those in residential areas. This may cause a faster decline or the withdrawal of such functions from residential areas. Similarly to other areas, the late maturation phase here shows a tendency towards functional, physical and economic diversification. According to the situative mapping, the transition is manifested by a shift from productive industrial uses towards service and 
retail, with all conflicts evolving from emerging competition with integrated areas in the adjacent city, as already seen in Rückmarsdorf (Interview 18 2012; Interview 19 2012).

\subsubsection{Case study region: Hamburg}

Hamburg comprises the core of the Hanseatic city of Hamburg and 112 additional local authorities. Hamburg (type I, see Figure 1) presents an example of a classic western German high-growth metropolis with a pronounced suburbanisation pattern which has both concentric and axial structures. Hamburg has expanded rapidly since the 1960s, particularly northwards and southwards. Whilst urban development policy and planning has, since the early 2000s, pursued the vision of a growing city with an emphasis on development of the centre, push factors are the lack of housing and consequent high prices that cause expansion into adjacent suburban municipalities. The following study areas were defined: the district of Eimsbüttel (core city of Hamburg), the town of Quickborn (closer commuting area) and the municipality of Tornesch (closer commuting area).

The Burgwedel micro area in Hamburg-Eimsbüttel is an example of a maturing housing area under need of consolidation. It consists of 1,600 rental apartments with some additional detached family houses, all constructed in the 1990s. A social housing apartment project has been designed to create a local centre at a commuter train station. However, due to the low purchase power of the inhabitants and low acceptance by the surrounding suburbanites, exacerbated by poor retail layouts, the area is far from becoming an integral urban centre for the adjacent settlement areas. Thus, local businesses in collaboration with the city ward office follow a strategy of marketing and branding, as well as physical adjustments of retail spaces (Interview 12012 ; Interview 2 2012; Interview 4 2012).

The Quickborn-West area in the north of the Hamburg metropolitan region represents an incremental expansion or re-densification at the development margin of a suburban municipality. In the last 10-15 years, the rather fragmented outskirts were consolidated by the infill of settlement gaps, the realignment of settlement area boundaries and a redensification with semi- and detached family houses as well as two- to three-storey apartment buildings. The quarter represents a suburbanisation area that is heavily mixed in demographic and housing terms. Ongoing generational change inspired the municipality to manage the movement of previous owners into apartments close to its centre. The case study represents a moderate densification guided by the municipality. The measures range from the designation of homes for senior citizens to municipal management and financing of related household removals. The local market for single-family and two-family homes is so vibrant that there are almost no vacant suburban properties in this subarea (Interview 3 2012).

Tornesch-Borstelweg shows a transition case whereby a mature commercial area which had lost its vitality transformed into a mixed residential district. This process was initiated by the displacement of production activities into a new commercial zone outside the compact settlement area. The municipality actively directs housing into this spatially integrated urban location, thus protecting itself from sprawl and minimising infrastructural costs (Interview 5 2012; Interview 6 2012).

\subsection{Discussing the empirical findings}

The cases studied show a significant diversity of individual development paths within the life cycle phases (see Table 2), thus confirming a basic argument provided by more recent studies on suburbanisation (see e.g. Keil 2013). The classic sequence of phases described at the beginning can be traced only in ideal cases, at most. For the growth phase, this involves stability in demand, the economy and planning regulations. Such is the situation in Quickborn (Hamburg region). When ideal maturity is reached, continuous consolidation by generational turnover and adjustments of physical structures to actual demands leads to a state of stable maturity (continued individual renewal). In the case of residential areas, the progress and the distinctiveness of the various phases are evident, due to the demographic life cycle, more clearly than in other districts, such as mixed or commercial and industrial locations. This also explains why residential cases of suburban renewal seem to be somehow over-represented in the literature, compared to commercial or industrial areas. Generally, stable maturity exists when continuous consolidation allows areas to remain at a certain level or to adjust without losing their social, physical or economic balance and future prospects. This has been documented in the cases of Tornesch (Hamburg region), Eimsbüttel (Hamburg region) and Hamm Römerstraße (Ruhr area).

Different external influences and internal situations may alter or disturb the life-cycle progression towards stable maturity, during both growth and maturity. Such deviations lead to the extension or end of phases, and open transitions into other states (Martin 2012). During the growth phase, significant changes in the real estate market, in the overall economic climate or locational preferences may alter (Borsdorf, Leipzig), slow down (Roter Rain III, Fritzlar), or even bring the started development of an area to a halt (Ahnatal, Kassel) or dilapidation (as mentioned in the third section of the Grimma case study area). Here, the importance of proactive rezoning becomes evident for allowing transitions to unfold (cf. Salet/Savini 2015). 
Table 2 Life cycles in the case-study areas

\begin{tabular}{llll}
\hline & Life cycles & & Transition \\
\hline $\begin{array}{l}\text { Strategies } \\
\text { Growth }\end{array}$ & Growth & Maturity & \\
Consolidation & Fritzlar/Roter Rain III & & Fritzlar/Roter Rain I \\
& Fritzlar/Roter Rain III & Fritzlar/Roter Rain II & Eimsbüttel/Burgwedel \\
& & Tornesch/Borstelweg & Ahnatal/Kammerberg \\
& & Hamm/Römerstraße & Grimma/Grimma-Süd \\
& & Vellmar/Musikerviertel & Gelen/Bertlich \\
& & & Leipzig-Altwest/Rückmarsdorf \\
\hline
\end{tabular}

During maturation, deviations from continuous consolidation are caused by changed societal conditions compared to those that enabled initial growth. On the one hand, a real estate boom or the enlargement of the core city into the suburban outskirts may lead to transitions of the area into an urban quarter. This qualitative enrichment or urbanisation of the suburbs (see Mace 2013) is what happened to Burgwedel (Hamburg-Eimsbüttel) on the micro level, as the compact housing of the case-study area was placed between older suburban settings. The best example on the local level, however, is the case study area in Grimma, where mature structures are simultaneously challenged by demographic changes (i.e., ageing of the population) and the outflux of young people for educational or job reasons (see Menzl 2007). Changes in demand concerning the functional use of space may lead to typologically or functionally mixed neighbourhoods, such as in the case of Tornesch, Hamburg. On the other hand, among metropolitan regions in demographic stagnation, the lack of demand generally leads to a delay of growth or maturation: stagnation or "over-ripening" (BMVBS 2013b: 125, 127) is the result, leading to conservation of the late maturity phase. This is what has happened especially in peripheral areas such as in HertenBertlich or in the remote areas of Kammerberg, Ahnatal. In the end, this may lead to a state of continuous decline accompanied by significant demographic ageing and physical dilapidation, as well as a functional loss of social infrastructure. This 'trap' of local development is sometimes assumed to be an outcome of deliberate policies (see Roberts 1991; Short/Hanlon/Vicino 2007). One example of this is Rückmarsdorf, Leipzig (see below). As the Bertlich case shows, exurban exclaves may remain stable in prolonged maturity by offering alternative lifestyle concepts or housing for specific identification groups (here mining workers).

The degree of deviation triggered by societal influences is related to the internal conditions of the area. As a general trigger of settlement area development, location and accessibility influence the development perspectives of settlement areas in urban, suburban and rural contexts, especially in terms of attracting new user generations. Divergent development paths during growth, maturation and eventual transition may be co-shaped by differences among particular sections of districts, as these may underlie specific conditions such as date of construction, access to or distance from particular services, or topographic (dis-) advantages. Such factors are relevant for all the case study areas, but are disproportionally effective in Vellmar, Kassel, as well as in Ahnatal, Kassel, and Grimma, Leipzig.

The case study investigation reveals not only a high variation of change in particular suburban areas, it also offers a glimpse of the differentiated planning practices used to deal with such change. Reacting to conditions and willingly adjusting the path in favour of - or to the disadvantage of particular areas may play a role in the strategies of planning and other stakeholders, most notably urban policy (Temkin/ Rohe 1996; Salet/Savini 2015). First, strategies of those in favour of the settlements' life cycle aim to implement measures which support growth during the growth phase, as is the case in Borsdorf, Leipzig, or Roter Rain III, Fritzlar. Such measures are mostly connected with the adjustment of planning laws and frameworks in order to adapt or redefine new development.

Disadvantaging strategies are, among the cases presented, being implemented in Rückmarsdorf, Leipzig, following a strategic target of preventing the area in question from reaching stable maturity or alternatively entering transition by adapting a fully or somewhat distinctive character. Top-down strategies implemented from the macro and meso levels onto the micro areas are merely institutional and thus rely on urban planning rules and policies including zoning, district planning, investment strategies or building permissions, often underpinned by general spatial models, such as the compact city in Leipzig. Bottomup initiatives, such as those seen in the cases of Resser Mark and Bertlich, Herten, are rather organised in concrete projects. 


\section{Concluding reflections}

The research documented in this paper reveals the highly differentiated set of developments and problems to be found in suburban areas and, likewise, the wide range of strategies undertaken by politics and planning. Policies and actions can be different within the observed levels (macro, meso, micro). While these policies depend on specific socio-demographic conditions and economic frameworks, the predominant life-cycle phase is of equal importance. Based on our findings, at least three idealistic strategies could be identified on each separate level, based on specific framework strategies aimed at promoting growth, consolidation and adaptation. These tactics have been cross-referenced and compared to different phases in life cycles in order to determine and categorise the different groups of strategies (see Table 2).

Among the different sites presented here, cases of consolidation were quite often found in environments characterised by transition and maturity. We could identify different situations based on a wide-ranging and uneven distribution of power between the local, municipal and regional levels. These constellations are able to steer the life cycle of suburban developments in particular directions. These regimes were not always as constructive as that found in the case of Resser Mark, but were generally able to steer transition in a particular direction. This may cause aberrations of the life-cyclic scenario, by accelerating, decelerating, or even fundamentally diverting its progress. Some systems may also - as Walker, Gunderson, Kinzig et al. (2006: 3) suggest - consequently remain "trapped in very resilient but undesirable regimes". All this occurs separately from fundamental adaptation or transformation processes, but it has a significant impact on the system's resilience.

Such a dynamic typology of the (sub-) urban life cycle accommodates a variety of transitions which, firstly, perfectly resemble the 'interactive ecology' of the re-consumption and reproduction of suburban spaces mentioned by McManus and Ethington (2007: $334 \mathrm{ff}$.). Secondly, this acknowledges suburbia as a 'place' of particular interests and stakeholders (Salet/Savini 2015), as indicated by the fact that suburbia undergoes a variety of different trajectories over time, rather than growth or decline only. Realising the potential of consolidation as a strategy involves the need to understand and influence specific multi-level settings by generating and managing local potentials rather than concentrating only on analysing and restoring the physical signs of the passage through life cycles, such as population shrinkage or economic decline. The essential question in this context is how to utilise the systemic potential of consolidation to strategically steer suburban development in areas that have lost their role within their regional context, and how they can regain the power and ability to influ- ence development trajectories over the long term. In the first instance, however, a systematic monitoring of the related (suburban) markets for development, for housing and commercial purposes could help provide the framework for anticipating and better understanding the development trajectories of suburban areas. Empirical data - understood in the widest sense of the term - on different levels and in varying amounts of detail can offer a variety of options for the institutions responsible: existing or pending problems can be identified to create mid- or long-term strategies. Here, life-cyclic approaches can serve as an important tool and sensitising element for conducting pre-emptive analyses, observation and strategy finding.

\section{References}

Bizer, K.; Dappen, C.; Deffner, J.; Heilmann, S.; Knieling, J.; Stieß, I. (2008): Nutzungszyklus von Wohnquartieren in Stadtregionen. Modellentwicklung. Hamburg. = neopolis working papers: urban and regional studies 3 .

BMVBS - Bundesministerium für Verkehr, Bau- und Stadtentwicklung (2012): Suburbaner Raum im Lebenszyklus - Studie. Zwischenbericht Februar 2012. Internal Paper. Berlin.

BMVBS - Bundesministerium für Verkehr, Bau- und Stadtentwicklung (2013a): Suburbaner Raum im Lebenszyklus - Studie. Endbericht Februar 2012. Internal Paper. Berlin.

BMVBS - Bundesministerium für Verkehr, Bau- und Stadtentwicklung (Hrsg.) (2013b): Suburbaner Raum im Lebenszyklus. Bonn. $=$ BMVBS-Online-Publikation 24/2013.

Cheshire, P.C. (2006): Resurgent Cities, Urban Myths and Policy Hubris: What We Need to Know. In: Urban Studies 43, 8, 12311246.

Choldin, H.M.; Hanson, C.; Bohrer, R. (1980): Suburban Status Instability. In: American Sociological Review 45, 6, 972-983.

CIMA Beratung + Management; Stadt Grimma (2002): Integriertes Stadtentwicklungskonzept der Stadt Grimma. Mügeln, Kemmlitz, Grimma.

CIMA Beratung + Management; Stadt Grimma (2015): Integriertes Stadtentwicklungskonzept der Stadt Grimma. Fortschreibung. Mügeln, Kemmlitz, Grimma.

Clapson, M. (2003): Suburban Century: Social Change and Urban Growth in England and the USA. Oxford/New York.

Clark, T.N.; Lloyd, R.; Wong, K.K.; Jain, P. (2002): Amenities Drive Urban Growth. In: Journal of Urban Affairs 24, 5, 493-515.

Clarke, G.; Martin, R.; Tyler, P. (2016): Divergent cities? Unequal urban growth and development. In: Cambridge Journal of Regions, Economy and Society 9, 2, 259-268.

Dittrich-Wesbuer, A.; Knapp, W.; Osterhage, F. (2010): Postsuburbanisierung und die „Renaissance der (Innen-)Städte“. Neue Entwicklungen in der Stadtregion. Detmold. = Metropolis und Region 6.

Forsyth, A. (2012): Defining Suburbs. In: Journal of Planning Literature $27,3,270-281$.

Friedrich, S. (2003): Umbau des Wohnens am Stadtrand. In: disP - The Planning Review 39, 155, 38-48.

Gotham, K.F. (2006): The Secondary Circuit of Capital Reconsidered: Globalization and the U.S. Real Estate Sector. In: American Journal of Sociology 112, 1, 231-275.

Hanlon, B. (2010): Once the American Dream. Inner-Ring Suburbs of the Metropolitan United States. Philadelphia.

Harris, R. (2010): Meaningful types in a world of suburbs. In: Clapson, M.; Hutchison, R. (eds.): Suburbanization in Global Society. Bingley, 15-47. = Research in Urban Sociology 10. 
Harris, R.; Larkham, P.J. (eds.) (1999): Changing Suburbs. Foundation, Form and Function. London.

Hesse, M. (2012): Suburbaner Raum - Annäherungen an Gegenstand, Inhalte und Bedeutungszuweisungen. In: Schenk, W.; Kühn, M.; Leibenath, M.; Tzschaschel , S. (eds.): Suburbane Räume als Kulturlandschaften. Hannover, 13-24. = Forschungs- und Sitzungsberichte der ARL 236

Holling, C.S. (1986): The resilience of terrestrial ecosystems: local surprise and global change. In: Clark, W.C.; Munn, R.E. (eds.): Sustainable Development of the Biosphere. Cambridge, 292-317.

Hoover, E.M.; Vernon, R. (1959): Anatomy of a Metropolis. The Changing Distribution of People and Jobs within the New York Metropolitan Region. Cambridge, MA.

Keil, R. (ed.) (2013): Suburban Constellations. Governance, Land, and Infrastructure in the 21 st Century. Berlin.

Keil, R.; Addie, J.-P.D. (2015): 'It's Not Going to be Suburban, It's Going to be All Urban': Assembling Post-suburbia in the Toronto and Chicago Regions. In: International Journal of Urban and Regional Research 39, 5, 892-911.

Kuhn, G. (2002): Suburbanisierung: Das Ende des suburbanen Zeitalters? In: Informationen zur modernen Stadtgeschichte 2, 5-12.

Lauster, N.T. (2016): The Death and Life of the Single-Family House. Lessons from Vancouver on Building a Livable City. Philadelphia.

Mace, A. (2013): City Suburbs. Placing suburbia in a post-suburban world. London/New York.

Martin, R. (2012): (Re)Placing Path Dependence: A Response to the Debate. In: International Journal of Urban and Regional Research 36, 1, 179-192.

McManus, R.; Ethington, P.J. (2007): Suburbs in transition: new approaches to suburban history. In: Urban History 34, 2, 317-337.

Menzl, M. (2007): Leben in Suburbia: Raumstrukturen und Alltagspraktiken am Rand von Hamburg. Frankfurt am Main.

Nijman, J. (2015): North American Suburbia in Flux. Introduction. In: Environment and Planning A 47, 1, 3-9.

Park, R.E. (1952): Human Communities: The City and Human Ecology. Glencoe.

Phelps, N.A.; Parsons, N.; Ballas, D.; Dowling, A. (2006): Post-Suburban Europe. Planning and Politics at the Margins of Europe's Capital Cities. Basingstoke.

Phelps, N.A.; Wood, A.M. (2011): The New Post-suburban Politics? In: Urban Studies 48, 12, 2591-2610.

Phelps, N.A.; Wood, A.M.; Valler, D.C. (2010): A Postsuburban World? An Outline of a Research Agenda. In: Environment and Planning A 42, 2, 366-383.

Polívka, J. (2016): Maturity, Resilience \& Lifecycles in Suburban Residential Areas. Dissertation, Technische Universität Dortmund.

Polívka, J.; Roost, F. (2011): Kerne, Adern und Ränder: Siedlungsund Bebauungsstruktur des Ruhrgebiets. In: Reicher, C.; Kunzmann, K.R.; Polívka, J.; Roost, F.; Utku, Y.; Wegener, M. (eds.):
Schichten einer Region. Kartenstücke zur räumlichen Struktur des Ruhrgebiets. Berlin, 38-78.

Prigge, W. (ed.) (1998): Peripherie ist überall. Frankfurt am Main/New York. $=$ Edition Bauhaus 1 .

Reicher, C.; Kunzmann, K.R.; Polívka, J.; Roost, F.; Utku, Y.; Wegener, M. (eds.) (2011): Schichten einer Region. Kartenstücke zur räumlichen Struktur des Ruhrgebiets. Berlin.

Roberts, S. (1991): A critical evaluation of the city life cycle idea. In: Urban Geography 12, 5, 431-449.

Salet, W.; Savini, F. (2015): The political governance of urban peripheries. In: Environment and Planning C 33, 3, 448-456.

Schenk, W.; Kühn, M.; Leibenath, M.; Tzschaschel, S. (eds.) (2012): Suburbane Räume als Kulturlandschaften. Hannover. = Forschungs- und Sitzungsberichte der ARL 236

Scott, A.J.; Carter, C.; Reed, M.R.; Larkham, P.; Adams, D.; Morton, N.; Waters, R.; Collier, D.; Crean, C.; Curzon, R.; Forster, R.; Gibbs, P.; Grayson, N.; Hardman, M.; Hearle, A.; Jarvis, D.; Kennet, M.; Leach, K.; Middleton, M.; Schiessel, N.; Stonyer, B.; Coles, R. (2013): Disintegrated development at the rural-urban fringe: Re-connecting spatial planning theory and practice. In: Progress in Planning 83, 1-52.

Setterfield, M. (1997): Should Economists Dispense with the Notion of Equilibrium? In: Journal of Post Keynesian Economics 20, 1, 47-76.

Short, J.R.; Hanlon, B.; Vicino, T.J. (2007): The Decline of Inner Suburbs: The New Suburban Gothic in the United States. In: Geography Compass 1, 3, 641-656.

Siedentop, S.; Fina, S. (2012): Who Sprawls Most? Exploring the Patterns of Urban Growth across 26 European Countries. In: Environment and Planning A 44, 11, 2765-2784.

Sieverts, T. (1997): Zwischenstadt. Zwischen Ort und Welt, Raum und Zeit, Stadt und Land. Braunschweig. = Bauwelt-Fundamente 118.

Temkin, K.; Rohe, W. (1996): Neighborhood Change and Urban Policy. In: Journal of Planning Education and Research 15, 3, 159170.

van den Berg, L.; Drewett, R.; Klaasen, L.H.; Rossi, C.; Fijverberg, C.H.T. (1982): A Study of Growth and Decline. Oxford.

Walker, B.H.; Gunderson, L.H.; Kinzig, A.P.; Folke, C.; Carpenter, S.R.; Schultz, L. (2006): A Handful of Heuristics and Some Propositions for Understanding Resilience in Social-Ecological Systems. In: Ecology and Society 11, 1, 13.

Wunsch, J.L. (1995): Review: The Suburban Cliche: The Suburban Trend by Harlan Paul Douglass. In: Journal of Social History 28, 3, 643-658.

Wüstenrot Stiftung (ed.) (2012): Zukunft von Einfamilienhausgebieten aus den 1950er bis 1970er-Jahren. Handlungsempfehlungen für eine nachhaltige Nutzung. Ludwigsburg. 